\title{
AIR LIMBAH AIR CONDITIONER (AC) SEBAGAI ALTERNATIF PENGGANTI PELARUT AKUADES PADA PROSES ANALISIS TOTAL ASAM PADA SALAK PONDOH (Salaca edulis)
}

\author{
Padya Sumarwanto', Yuni Hartati' ${ }^{2}$, Mukhamad Irfan ${ }^{3}$ \\ ${ }^{1}$ Fakultas Farmasi Universitas Gadjah Mada \\ ${ }^{2}$ Fakultas Biologi Universitas Gadjah Mada \\ ${ }^{3}$ Fakultas Teknologi Pertanian Universitas Gadjah Mada, Mukhamadirfan@ugm.ac.id
}

Submisi: 28 Oktober 2018; Penerimaan: 30 Juli 2019

\begin{abstract}
ABSTRAK
Kondensasi atau pengembunan dari Air Conditioner ( $A C$ ) kantor atau laboratorium berupa air, biasanya ditampung ke dalam wadah jerigen atau bahkan dibiarkan menetes di tempat terbuka. Laboratorium Pangan dan Gizi Fakultas Teknologi Pertanian selalu menggunakan $A C$, sehingga air AC yang terkondensasi di tampung dalam jerigen ternyata air yang dihasilkan cukup banyak untuk setiap harinya. Air ini cukup jernih mirip dengan akuades, sehingga kemungkinan bisa digunakan sebagai pelarut ataupun pengencer dalam analisis total asam pada salak pondoh (Salacca edulis)

Tujuan penelitian ini untuk memanfaatkan air AC sebagai pengganti air akuades dalam proses analisis total asam dengan metode titrasi. Adapun parameter yang diukur meliputi : Total asam, $\mathrm{pH}$, dan berat jenis terhadap air kondensasi AC dengan akuades.Sebagai pembanding digunakan akuades. Berdasarkan hasil analisis yang diperoleh,berat jenis air AC sebesar $1.006 \pm 0.001$ sedangkan akuades sebesar 1.0152 $\pm 0.0001 \mathrm{~kg} . \mathrm{m}^{3}$. Keasaman air AC senbesar $6.28 \pm 0.01$. Sedangkan akuades sebesar $\overline{6}, 8267 \pm 0.02$. Hasil analisis total asam (dihitung sebagai asam tanat) pada salak pondoh (Salacca edulis) dengan pelarut AC sebesar 6,8182\% 0.02 . Sedangkan dengan pelarut akuades sebesar 6,8237 \pm 0.007. Dari hasil analisis menunjukkan bahwa menggunakan air AC sebagai pelarut bisa digunakan untuk analisis total asam.
\end{abstract}

Kata kunci : Air AC, akuades, salak pondoh (Salacca edulis), total asam, titrasi

\section{PENDAHULUAN}

Beberapa jenis AC yang sering digunakan di perkantoran atau laboratorium memiliki air sisa buangan dari kondensasi AC tersebut. Semua orang akan pasti tahu itu adalah air limbah yang langsung dibuang kesaluran air atau pipa khusus dan tidak memiliki kegunaan lain. Bagi orang laboran, teknisi atau Pranata Laboratorium Pendidikan pasti akan berpikir ulang untuk membuang air $A C$ tersebut, sebab masih ada beberapa manfaatnya air buangan AC yang mungkin belum diketahui banyak orang. Selain banyak manfaatnya air AC ini hamper serupa dengan air suling namun tidak terlalu bersih. Untuk itu air AC dapat digunakan pula sebagai analisis $\mathrm{N}$
Total pada metode mikrokjeldahl (astuti dan Irfan, 2016). Analisis di laboratorium untuk analisis Total asam selama ini menggunakan pelarut akuades. Penelitian ini mencoba untuk menggunakan air limbah AC pada analisis total asam salak Pondoh (Salacca edulis)

Kondisi iklim tropis di Indonesi, memiliki kekayaan melimpah, khususnya buah - buahan. Tumbuh dan berkembang berbagai jenis buah buahan sangat memungkinkan tumbuh dan berkembang dengan baik. Banyaknya jenis buah-buahan yang tumbuh dan berkembang di Indonesia, salak pondoh. Di daerah kabupaten Sleman banyak kita jumpai salak pondoh tersebut. 
Salak (Salacca edulis) adalah salah satu buah tropis asli Indonesia. Buah ini termasuk dalam keluarga Palmae dengan batang- batang tertutup oleh pelepah daun yang tersusun sangat rapat dan juga buahnya bersisik coklat tersusun didalam tandan (tersekap diantara pelepah daun). Salak mempunyai rasa daging yang kelat, asam, dan manis. Ada beberapa varietas salak yang sudah dikenal sebagian masyarakat dan trsebar di berbagai daerah di Indonesia, salah satunya yaitu varietas salak pondoh. Salak pondoh menjadi salah satu varietas yang populer diantara varietas salak yang lain di Indonesia, maka dari itu buah salak pondoh ini memiliki peluang peluang agribisnis yang menguntungkan dimasa mendatang sejalan dengan meningkatnya konsumsi buah-buahan dalam negeri maupun permintaan luar negeri (Widyastuti,1966).

Sebagaimana umumnya buah dan sayuran, salak masih melangsungkan proses metabolisme setelah dipanen. Reaksi metabolisme akan mengakibatkan perubahan mutu, penampakan dan kondisi buah. Perubahan tersebut disebapkan terjadinya penguapan air, konfersi enzimatis menjadi gula, pembentukan atau pelepasan flavor, konversi enzimatis senyawa pektin, sintesa atau degradasi pigmen, kerusakan vitamin dan lainnya (Pantastico, 1989).

Penelitian ini bertujuan untuk mengetahui perbedaan pelarut dengan menggunakan Air Conditioner (AC) sebagai pelarut dibandingkan dengan pelarut akuades, pada analisis Total asam dengan metode titrasi. Adapun hasil penelitian ini dapat digunakan sebagai informasi tentang kemungkinan penggunaan air limbah AC sebagai pelarut alternatif selain akuades, sehingga dapat mengurangi ketergantungan pada suplier akuades.

\section{METODE PENELITIAN Bahan-bahan}

Bahan yang digunakan antara lain salak pondoh yang didapatkan dari Turi, Sleman, Yogyakarta; akuades didapat dari Chemix Pratama; air limbah AC (Panasonic model CS/KN 9TKJ, 250 v tahun produksi 2015) didapatkan dari Laboratorium Pangan dan Gizi FTPUGM; Phenop Ptalin Merc $1 \%$; $\mathrm{NaOH}$ Merc $0.01 \mathrm{~N}$; dan Etanol Merc

\section{Peralatan}

Peralatan yang digunakan antara lain pisau, parutan, timbangan analitik (Fujitsu FS - AR-210, $\max =210 \mathrm{gr}$, e= $1 \mathrm{mg}, \mathrm{d}=0,1 \mathrm{mg}$ ), $\mathrm{pH}$ meter (Crison $\mathrm{pH}$ 25), piknometer $25 \mathrm{ml}$, Gelas Ukur 100 $\mathrm{ml}$, Gelas arloji, beker gelas $250 \mathrm{ml}$, spatula, labu tkar $100 \mathrm{ml}$, pipet ukur 10 $\mathrm{ml}$, pipet tetes, statif, klem statif, buret $25 \mathrm{ml}$

\section{Waktu dan tempat Penelitian}

Penelitian dilakukan dilaboratorium Pangan dan Gizi Departemen Teknologi Pangan dan Hasil Pertanian (TPHP) Fakultas Teknologi Pertanian (TP) Universitas Gadjah Mada. Pada bulan Mei 2018.

\section{Prosedur Penelitian}

Salak diambil dari penjual salak yang ada di sepanjang jalan magelang, sedangkan air limbah AC diambil di lingkungan Departemen Teknologi Pangan dan Hasil Pertanian (TPHP), Fakultas Teknologi Pertanian (FTP), Universitas Gadjah Mada (UGM). Akuades dibeli dari suplair diukur keasamannya menggunakan $\mathrm{pH}$ meter Hanna HI 2210, dan berat jenis pakai piknometer pyrek $10 \mathrm{ml}$. Air limbah AC di tamping pada wadah yang bersih dan saluran pipa juga dibersihkan bagian 
luarnya terlebih dahulu. Dalam pengambilan ini usahakan dua hari sudah diambil dari kondensasi. Selanjurnya air AC bisa langsung dipergunakan sebagai pelarut. Dalam penyimpanan air AC kalau di tempatkan pada wadah yang terbuat dari plastic jangan lebih dari satu bulan. Penyimpanan akan lebih bagus pada tempat penyimpanan yang terbuat dari kaca supaya bisa bertahan lama dan tidak mudah tumbuh lumut pada tempat penyimpanan. Selai air AC ada juga akuades digunakan sebagai semua pelarut sampel dan reagen untuk analisis Total asam dengan metode titrasi kecuali PP $1 \%$ pelarutnya memakai alkohol (Sadler dan Murphy, 1988). Kenudian hasilnya dibandingkan antara menggunakan pelarut air $\mathrm{AC}$ dan pelarut akuades.

\section{Analisis keasaman dengan menggunakan pH meter}

Nilai $\mathrm{pH}$ dapat diukur langsung dengan $\mathrm{pH}$ meter menggunakan elektrode gelas kombinasi dengan menggunakan larutan sangga $\mathrm{pH} 7,0$ dan $\mathrm{pH} 4,0$.

\section{Analisis densitas}

Piknometer yang sudah bersih dan kering ditimbang kemudian diisi dengan akuades bersuhu 20-30 ${ }^{\circ} \mathrm{C}$ sampai penuh ditutup, kemudian botol direndam dalam bak air yang bersuhu $25^{\circ} \mathrm{C}$ dengan toleransi $0,2^{\circ} \mathrm{C}$ selama 30 menit, diangkat dan dikeringkan piknometer yang berisi air, ditimbang dan dicatat hasilnya. Dikosongkan kembali piknometer dengan menuangkan air yang ada di dalamnya, kemudian dikeringkan dan diisi lagi dengan bahan yang akan diukur densitasnya (ukur Suhu bahan Terlebih dahulu) dan ditimbang piknometer yang berisi larutan tersebut (Apriyantono,1988)

\section{Analisis total asam dengan metode titrasi}

Pengukuran tingkat keasaman dilakukan dengan menggunakan metode titrasiasam. Daging buah salak diparut sampai halus, timbang dengan gelas arloji, larutkan dalam beker gelas sampai sempurna. Tuang dalam labu takar $100 \mathrm{ml}$, larutkan sampai tanda. Tuang larutan dalam erlenmeyer $250 \mathrm{ml}$, tambahkan indikator PP $1 \%$ beberapa tetes. Lakukan titrasi dengan $\mathrm{NaOH}$, sampai warna terbentuk merah jambu. Analisis data yang dilakukan dalam pengukuran parameter kandungan total asam dalam buah salak sebagai berikut ( Sadler dan Murphy, 1988) :

$$
\begin{aligned}
& \% \text { Total Asam } \\
& =\frac{(\text { ml NaOH } x N \mathrm{NaOH}) \times F P}{\text { berat sampel }} \times 100 \%
\end{aligned}
$$

Dimana :

$\mathrm{ml} \mathrm{NaOH}=\mathrm{NaOH}$ yang terpakai (ml)

$\begin{array}{lll}\mathrm{N} \mathrm{NaOH} & =\text { Normalitas } & \mathrm{NaOH} \\ & (0,01 \mathrm{~N}) \\ \mathrm{Fp} & =\text { Faktor pengenceran }\end{array}$

Dari hasil penelitian menggunakan pelarut Air Conditioner (AC) didapat kan data 6,8182\% 0,02. Sedangkan menggunakan pelarut akuades di dapatkan data $6.8237 \% \pm$ 0,007 .

Tabel 1. Hasil Analisis Total asam pada salak

\begin{tabular}{lc}
\hline \multicolumn{1}{c}{ Pelarut } & Hasil \% \\
\hline Akuades & $6,8237 \pm 0,007$ \\
Air Conditioner (AC) & $6,8182 \pm 0,02$ \\
\hline
\end{tabular}

Dari tabel 1 dapat dilihat bahwa hasil analisis total asam dengan titrasi pada salak pondoh, antara pelarut akuades dan air conditioner tidak begitu jauh berbeda. Air limbah AC dapat digunakan sebagai pelarut alternatif pada analisis total asam dengan sampel salak pondoh. 


\section{HASIL DAN PEMBAHASAN}

Karakterisasi Air limbah AC dan akuades dilakukan dengan analisis keasaman dan berat jenis. Hasil analisis pada tabel 1 menunjukkan bahwa berat jenis antara air limbah AC dan air akuades tidak beda jauh. Keasaman yang didapatkan juga tidak beda jauh antara air limbah ac dan akuades. Dari uji berat jenis dan keasaman antara air limbah AC dan air akuades tidak berbeda jauh. Sehingga ada kemungkinan air limbah AC dapat digunakan sebagai pengganti air akuades.

Tabel 1. Hasil karakterisasi air limbah AC dan akuades

\begin{tabular}{lllll}
\hline Parameter & \multicolumn{2}{l}{ Air limbah } & Akuades & \\
& AC & & & \\
\hline $\mathrm{pH}$ & 6.28 & \pm & 6,8267 & \pm \\
& 0.01 & & 0.02 & \\
Berat Jenis & 1.006 & \pm & 1.0152 & \pm \\
$\left(\mathrm{kgm}^{3}\right)$ & 0.001 & & 0.0001 & \\
\hline
\end{tabular}

Analisis total asam dengan metode titrasi dengan pelarit air limbah AC dan pelarut air akuades dengan sampel salak pondoh (salaca edulis) dapat dilihat pada tabel 2. Dari tabel 2 dapat dilihat bahwa hasil analisis total asam pada salak pondoh (salaca edulis) dengan menggunakan air limbah AC $6,8182 \% \pm 0.02$ sedangkan menggunakan pelarut air akuades di dapatkan $6,8237 \pm 0.007$, hasil tersebut tidak menunjukkan perbedaan yang signifikan. Air limbah AC dapat digunakan sebagai pengganti air akuades dalam analisis total asam dengan metode titrasi.

Tabel 2. Hasil analisis Total asam pada salak pondoh

\begin{tabular}{lll}
\hline Parameter & $\begin{array}{l}\text { Air limbah } \\
\text { AC }\end{array}$ & $\begin{array}{l}\text { Air } \\
\text { akuades }\end{array}$ \\
\hline Total Asam & $6,8182 \% \pm$ & $6,8237 \% \pm$ \\
titrasi & 0.02 & 0.007 \\
\hline
\end{tabular}

\section{KESIMPULAN}

Dari analisis yang telah dilakukan bahwa analisis total asam menggunakan metode titrasi dengan menggunakan pelarut air limbah AC adalah 6,8182\% tidak berbeda jauh dengan analisis total asam menggunakan metode titrasi dengan pelarut akuades yaitu $6,8237 \%$. Sehingga air limbah AC dapat digunakan sebagai pelarut alternatif dalam analisis total asam dengan metode titrasi pada salak pondoh.

\section{SARAN}

Untuk kegiatan Laboratorium khususnya pada bidang pendidikan dengan banyaknya Praktikum, bisa menggunakan air limbah Air Conditioner kususnya analisis Total asam dengan metode titrasi pada buah Salak Pondoh (Salacca edulis), bisa juga untuk mengarahkan mahasiswa yang sedang penelitian dengan analisis yang sama

\section{UCAPAN TERIMAKASIH}

Ketua Departemen Teknologi Pangan dan Hasil Pertanian dan Kepala Laboratorium Pangan dan Gizi yang telah memberi fasilitas untuk penelitian ini serta Teman-teman Pranata Laboratorium Pendidikan di lingkungan Fakultas Teknologi Pertanian Universitas Gadjah Mada yang memberi semangat dalam penelitian dan penyususnan Laporan.

\section{DAFTAR PUSTAKA}

Suhardi, Tranggono dan Santosa.U. 1997, Perubahan Kimia dan Sensoris Buah Salak Pondoh Selama Penyimpanan Termodifikasi. Agritech vol 17 (1). Halaman 6-9

Hartarto,R. 2002. Diklat Fisiologi Pasca Panen dan Sayur-sayuran. Universitas Lampung, Bandar lampung. 51 Halaman 
P. Sumarwanto, Y. Hartati, dan M. Irfan Nol 1 (3) 2019, 33-39

Hartarto, R. Raharjo, B dan Suhardi.2000. Model Perubahan Gula Buah Salak Pondoh (Salacca edulis REINW cultifar pondoh) pada kondisi Admosfer Termodofikasi. Agritech Vol 20 (1) Halama 10-13

Trihapsari, K.I. 1991. Penyimpanan Salak Pondoh (Salacca edulis) dengan Sistem Udara Termodifikasi [skripsi], Fakultas Teknologi Pertanian IPB, Bogor

Djafar, T.F dan Mudjislhono, R. 1998, Perubahan Sifat Fisik danm Kimia Buah Salak Pondoh Berbagai Perlakuan Penyimpanan Buah Segar, Buletin Agro Industi No.05. Halaman 12-23

Rachmawati, M. 2010. Kajian Sifat Kimia Salak Pomdoh (Salacca edulis
Renw) Dengan Pelapisan Khitosan Selama Penyimpanan Untuk Memproduksi Masa Simpannya. Jurnal Teknologi Pertanian 6 (1). Halamam 20-24

Widyastuti, Y.E. 1996. Mengenal Buah Unggul Indonesia. Penebar Swadaya, Jakarta. 258 Halaman Apandi, M. 1984. Teknologi Buah dan Sayur. Alumni, Bandung. 106 Halaman

Kartasaputra, A.G. 1994. Teknologi Penanganan Pasca Panen, PT. Rineka Citra.252 Halaman

Pujimulyani, D. 2009. Teknologi Pengolahan Sayur dan Buahbuahan . Graha IImu, Yogyakarta. 288 Halaman 